\title{
GSTP1 Gene
}

National Cancer Institute

\section{Source}

National Cancer Institute. GSTP1 Gene. NCI Thesaurus. Code C18519.

This gene is involved in phase II metabolism of both endogenous compounds and xenobiotics. 